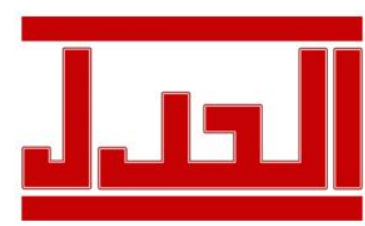

ISSN: $1979-4940$

E-ISSN : 2477-0124
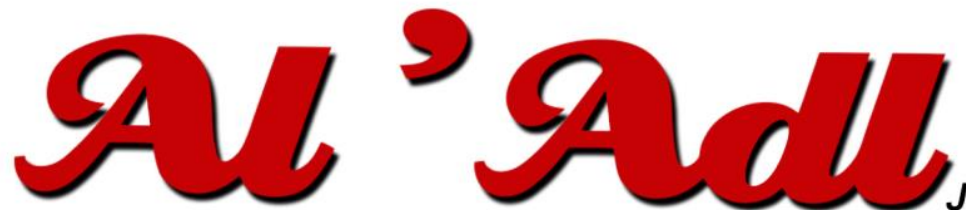

Jurnal Hukum

Editorial Office: Faculty of Law, Islamic University Of Kalimantan,

Jalan Adhyaksa No. 2 Kayutangi Banjarmasin, Kalimantan Selatan, Indonesia (70123)

Email: al_adl@uniska-bjm.ac.id

Web: http://ojs.uniska-bjm.ac.id

\section{PERLINDUNGAN HUKUM DAN HAK MEMPEROLEH KESELAMATAN KERJA BAGI TENAGA KESEHATAN AKIBAT PANDEMI COVID-19}

\author{
Dwi Armeilia \\ Magister Hukum Universitas Singaperbangsa Karawang \\ Jl. HS. Ronggo Waluyo, Paseurjaya, Telukjambe Timur, Kab. Karawang - 41361 \\ Email: dwiarmeilia@gmail.com
}
Submitted
: 2 Maret 2021
Revised
Accepted
Published
2021
: 1 Mei 2021

(C) Licence by CC BY-NC-SA

\begin{abstract}
Medical workers are a noble profession, especially amid the Covid-19. One of the aspects that have received the most impact from this pandemic is in the health sector. The problems in the health sector have become increasingly dangerous in the era of the Covid-19 Pandemic in Indonesia. The current condition is a concern for all people regarding efforts to control and overcome the Covid-19 Pandemic in Indonesia. This includes doctors and other health professionals. The number of deaths of medical personnel, especially doctors and nurses, is increasing. This research focuses on Indonesia's legal policies regulating protection and the fulfillment of safety work rights for health workers who are dealing with the pandemic. The legal method used in this research is normative legal research. The results show that legal protection and fulfillment of the right to safety for medical personnel have been regulated in legislation. However, these provisions do not specifically regulate the potential dangers of the spread of the Covid-19 virus.
\end{abstract}

Keywords : Areas Legal Protection; Safety in the workplace; Medical Profession.

\title{
Abstrak
}

Tenaga kesehatan adalah sebuah profesi yang mulia terutama ditengah krisis pandemi Covid-19. Salah satu aspek yang menerima dampak yang paling besar dari pandemi ini adalah di bidang kesehatan. Problematika di bidang kesehatan semakin terlihat jelas di era Pandemi Covid-19 di Indonesia. Kondisi saat ini tentunya menjadi kekhawatiran bagi seluruh masyarakat terkait dengan upaya pengendalian dan penanggulangan Pandemi Covid19 ini di Indonesia. Termasuk juga di kalangan medis dan tenaga kesehatan lainnya. Kematian tenaga medis khususnya dokter dan perawat yang semakin bertambah. Adapun penelitian ini difokuskan pada kebijakan hukum positif Indonesia mengatur perlindungan hukum atas hak keselamatan kerja bagi tenaga kesehatan yang menangani pandemi Covid-19. Penelitian hukum yang digunakan dalam penelitian ini adalah penelitian hukum normatif. Hasil penelitian menunjukan bahwa perlindungan hukum dan pemenuhan hak atas keselamatan kerja bagi tenaga medis yang menangani pandemi covid-19 sudah diatur didalam perundang-undangan Indonesia. Kendati demikian ketentuan-ketentuan tersebut belum mengatur secara khusus mengenai potensi bahaya 
penyebaran virus covid-19.

Kata Kunci : Perlindungan Hukum; Keselamatan Kerja; Tenaga Kesehatan.

\section{PENDAHULUAN}

Saat ini dunia sedang berjuang menghadapi Covid-19. Coronovirus Disease 2019 (Covid-19) adalah penyakit menular yang disebabkan oleh Severe Acute Respiratory Syndrome Coronavirus 2 (SARS-CoV-2). SARS-Cov-2 merupakan corona virus jenis baru yang baru diidentifikasi sebelumnya pada manusia. ${ }^{1}$ Berdasarkan data yang telah dipublikasikan oleh Ikatan Dokter Indonesia pada tanggal 6 April 2020, terdapat 24 Dokter (6 diantaranya adalah Dokter Gigi) yang gugur di tengah pandemi Covid-19. Sedangkan berdasarkan data per tanggal 8 Mei 2020 yang dirilis oleh Persatuan perawat Nasional Indonesia (PPNI), angka terpapar Covid-19 para tenaga kesehatan (perawat) terus bertambah. Angka Orang Dalam Pemantauan (ODP) 596 orang, Pasien Dalam Pengawasan (PDP) 48 orang, Orang Tanpa gejala (OTG) 97 orang, Positif 53 orang, dan meninggal 19 orang. ${ }^{2}$ Hal ini tentu merupakan sebuah ironi yang perlu menjadi perhatian bahwa tenaga kesehatan baik dokter, perawat maupun tenaga administrasi rumah sakit perlu mendapat perlindungan hukum dari pemerintah. Tenaga kesehatan rela mengabdikan dirinya untuk melayani kesehatan masyarakat dan bahkan mengorbankan nyawanya dan keluarganya demi menanggulangi penyebaran Covid-19. Profesi tenaga kesehatan adalah sebuah profesi yang mulia dan pada profesi tersebut semakin terejawantahkan di tengah krisis pandemi Covid-19. ${ }^{3}$

Salah satu aspek yang menerima dampak yang paling besar dari pandemi ini adalah di bidang kesehatan. Problematika di bidang kesehatan semakin terlihat jelas di era Pandemi Covid-19 ini di Indonesia. Kondisi saat ini tentunya menjadi kekhawatiran bagi seluruh masyarakat terkait dengan upaya pengendalian dan penanggulangan Pandemi Covid-19 ini di Indonesia. Termasuk juga di kalangan medis dan tenaga kesehatan lainnya. Kematian tenaga medis khususnya dokter dan perawat yang semakin bertambah. Data terakhir 101 teman sejawat dokter meninggal dikarenakan Covid-19 (Per 31 Agustus 2020).

Rasio kematian tenaga medis dan tenaga kesehatan di Indonesia termasuk tinggi bila dibandingkan di negara lain. 1,36 \% kematian tenaga kesehatan Indonesia karena Covid-19

${ }^{1}$ Heldavidson, "First Covid-19 Case Happened In November, China Government Records Show Report 2020", diakses dari https://www.theguardian.com/world/2020/mar/13/first-covid-19-case-happened-innovember-china-government-records-show-report. (Diakses tanggal 20 Februari 2021)

${ }^{2}$ Merdeka.com/Data PPNI: Perawat Meninggal Akibat Covid-19, (Diakses tangal 6 Maret 2020).

${ }^{3}$ Theresia Louize Pesulima dan Yosia Hetharie, (2020), "Perlindungan Hukum Terhadap Keselamatan Kerja Bagi Tenaga Kesehatan Akibat Pandemi Covid-19”, Jurnal Sasi, Vol. 26, No. 2, April-Juni 2020, hlm. 280 
(101 orang) dibanding dengan total kematian terkonfirmasi Covid-19 per 31 Agustus 2020 (7417 orang). Oleh karna itu perlu dilakukan upaya-upaya untuk melakukan "Medical Safety And Protection" bagi Tenaga Medis (dalam hal ini anggota IDI) agar tetap dapat melakukan pelayanan kesehatan tetapi terlindungi dan terjamin keselamatannya sebagai upaya meminimalisir risiko tertular virus Covid-19 ini.

Jumlah penduduk yang terinfeksi dan meninggal akibat pandemi Covid-19 meningkat sampai saat ini. Pada 2 November 2020, tercatat 412.784 penduduk Indonesia terinfeksi Covid-19 dan sebanyak 13.943 orang diantaranya meninggal akibat wabah ini. Situasi pandemi Covid-19 menuntut peran dokter dan tenaga kesehatan dengan kompetensi tertentu. ${ }^{4}$ Sehingga diperlukan suatu langkah dan upaya akselerasi protocol dan panduan perlindungan dokter dalam menjalankan praktik kedokteran di Era Covid-19 sangat penting untuk memberikan perlindungan dan keselamatan para Dokter dalam menjalankan Praktik Kedokteran dan pelayanan kesehatan untuk seluruh masyarakat Indonesia.

\section{RUMUSAN MASALAH}

Berdasarkan latar belakang yang dijelaskan diatas maka permasalahan yang diangkat dalam penelitian ini adalah sebagai bagaimana kebijakan hukum positif Indonesia mengatur perlindungan hukum atas hak keselamatan kerja bagi tenaga kesehatan yang menangani pandemi Covid-19?

\section{METODE PENELITIAN}

Penelitian dalam ilmu hukum berusaha untuk menampilkan hukum secara integral sesuai dengan kebutuhan kajian ilmu hukum itu sendiri. ${ }^{5}$ Sebenarnya ilmu hukum mempunyai ciri-ciri sebagai ilmu yang bersifat preskriptif dan terapan. Dalam preskriptif, ilmu hukum mempelajari tujuan hukum, nilai-nilai keadilan dalam suatu hukum, baik buruk suatu aturan hukum, konsep-konsep dan norma hukum. sedangkan dalam ilmu terapan, ilmu hukum menetapkan suatu prosedur, ketentuan-ketentuan dan batasan-batasan dalam menegakan suatu aturan hukum. ${ }^{6}$

\footnotetext{
${ }^{4}$ Tri Aktariyani, Darwito, Rimawati, \& Laksono Trisnantoro, (2020), "Perlindungan Hukum Residen Dalam Penanganan Pasien Covid-19 Di Indonesia", Jurnal Kebijakan Kesehatan Indonesia : JKKI, Vol.9, No.4, Desember 2020, hlm. 225-231

${ }^{5}$ Yati Nurhayati, (2013) "Perdebatan Antara Metode Normatif Dengan Metode Empirik Dalam Penelitian Ilmu Hukum Ditinjau Dari Karakter, Fungsi, dan Tujuan Ilmu Hukum” Jurnal Al Adl, Vol 5, No 10, hlm.15

${ }^{6}$ Yati Nurhayati, Pengantar Ilmu Hukum, Nusa Media, Bandung, 2020, hlm. 9.
} 
Penelitian hukum yang digunakan dalam penelitian ini adalah penelitian hukum normatif. Peter Mahmud Marzuki menjelaskan “... suatu proses untuk menemukan suatu aturan hukum, prinsip prinsip hukum, maupun doktrin-doktrin hukum untuk menjawab permasalahan hukum yang dihadapi. ... Penelitian hukum normatif dilakukan untuk menghasilkan argumentasi, teori atau konsep baru sebagai preskripsi dalam menyelesaikan masalah yang dihadapi. ${ }^{7}$

Metode penelitian hukum normatif dapat dimaknai sebagai penelitian hukum dalam tataran norma, kaidah, asas-asas, teori, filosofi, dan aturan hukum guna mencari solusi atau jawaban atas permasalahan baik dalam bentuk kekosongan hukum, konflik norma, atau kekaburan norma. Dengan demikian metode penelitian hukum normatif memiliki karakteristik sebagai penelitian kepustakaan atau literature research yang berbeda dengan metode penelitian empiris (non-doktrinal) yang berkarakteristik penelitian lapangan (field study). ${ }^{8}$

Soerjono Soekanto dan Sri Mamudji memperkuat pendapat mengenai penelitian normatif adalah penelitian yang dilakukan dengan cara meneliti: ${ }^{9}$

a. Penelitian terhadap asas-asas hukum, yaitu penelitiian terhadap unsur-unsur hukum baik unsur ideal (normwissenschaft / sollenwissenschaft) yang menghasilkan kaidahkaidah hukum melalui filsafat hukum dan unsur real (tatsachenwissenschaft / seinwissenschaft) yang menghasilkan tata hukum tertentu (tertulis).

b. Penelitian terhadap sistematika hukum, yaitu mengadakan identifikasi terhadap pengertian pokok dalam hukum seperti subyek hukum, hak dan kewajiban, peristiwa hukum dalam peraturan perundangan.

c. Penelitian terhadap taraf sinkronisasi vertikal dan horizontal, yaitu meneliti keserasian hukum positif (peraturan perundagan) agar tidak bertentangan berdasarkan hierarki perundang-undangan (stufenbau theory).

d. Perbandingan hukum, yaitu membangun pengetahuan umum mengenai hukum positif dengan membandingkan sistem hukum di satu negara dengan sistem hukum di negara lainnya

e. Sejarah hukum, yaitu meneliti perkembangan hukum positif (peraturan perundangan) dalam kurun waktu tertentu (misalnya hukum tanah, perkawinan, perpajakan perusahaan dsb).

${ }^{7}$ Peter Mahmud Marzuki. (2005). Penelitian Hukum, Jakarta: Kencana., hlm. 35 sebagaimana dikutip didalam M. Yasir Said \& Yati Nurhayati, (2020), "Paradigma Filsafat Etika Lingkungan Dalam Menentukan Arah Politik Hukum Lingkungan", Al-Adl Jurnal Hukum, Vol.12, No.1 Januari 2020, hlm.39-60.

${ }^{8}$ Nurhayati, Y., Ifrani, I., \& Said, M. Y. (2021). Metodologi Normatif Dan Empiris Dalam Perspektif Ilmu Hukum. Jurnal Penegakan Hukum Indonesia, 2(1), 1-20. https://doi.org/10.51749/jphi.v2i1.14

9 Soerjono Soekanto dan Sri Mamuji. (1995). Penelitian Hukum Normatif, Suatu Tinjauan Singkat, Jakarta: RajaGrafindo, hlm. 15. 


\section{PEMBAHASAN}

\section{A. Konsep Perlindungan Hukum Dalam Pemenuhan Hak Tenaga Kesehatan}

Manusia merupakan makhluk ciptaan Tuhan yang sejak lahir memiliki hak-hak dasar yaitu hak untuk hidup, hak untuk dilindungi, hak untuk bebas dan hak-hak lainnya. Jadi, pada dasarnya setiap manusia memiliki hak untuk dilindungi termasuk dalam kehidupan bernegara. ${ }^{10}$ Dengan kata lain, setiap warganegara akan mendapat perlindungan dari Negara. Hukum merupakan sarana untuk mewujudkannya sehingga muncul teori perlindungan hukum. Ini adalah perlindungan akan harkat dan martabat serta hak-hak asasi manusia berdasarkan ketentuan hukum oleh aparatur negara. ${ }^{11}$ Dengan begitu, perlindungan hukum merupakan hak mutlak bagi setiap warganegara dan merupakan suatu kewajiban yang harus dilakukan oleh pemerintah, mengingat Indonesia yang dikenal sebagai negara hukum. Perlindungan hukum adalah adanya upaya melindungi kepentingan seseorang dengan cara mengalokasikan sesuatu kekuasaan kepadanya untuk bertindak dalam kepentingannya sendiri. Selanjutnya dikemukakan juga bahwa salah satu sifat dan sekaligus merupakan tujuan dari hukum adalah memberikan perlindungan kepada masyarakat. Oleh karena itu, perlindungan hukum terhadap masyarakat tersebut harus diwujudkan dalam bentuk adanya kepastian hukum. ${ }^{12}$

Awal mula dari munculnya teori perlindungan hukum ini bersumber dari teori hukum alam atau aliran hukum alam. Aliran ini dipelopori oleh Plato, Aristoteles (murid Plato), dan Zeno (pendiri aliran Stoic). Menurut aliran hukum alam menyebutkan bahwa hukum itu bersumber dari Tuhan yang bersifat universal dan abadi, serta antara hukum dan moral tidak boleh dipisahkan. Para penganut aliran ini memandang bahwa hukum dan moral adalah cerminan dan aturan secara internal dan eksternal dari kehidupan manusia yang diwujudkan melalui hukum dan moral. Fitzgerald menjelaskan teori pelindungan hukum Salmond bahwa hukum bertujuan mengintegrasikan dan mengkoordinasikan berbagai kepentingan dalam masyarakat karena dalam suatu lalu lintas kepentingan, perlindungan terhadap kepentingan tertentu hanya dapat dilakukan dengan cara membatasi berbagai kepentingan di lain pihak. Kepentingan hukum adalah mengurusi hak dan kepentingan manusia, sehingga hukum

\footnotetext{
${ }^{10}$ Ifrani, I., Topan, M. ., Safitri, N. ., \& Erniyati, T. (2021). "Regional Policy In Managing Oil Palm Waste As Renewable Energy In South Kalimantan Province", International Journal of Law, Environment, and Natural Resources, 1(1), 1-10. https://doi.org/10.51749/injurlens.v1i1.6

${ }^{11}$ Noor Rahmah, A., Ridha, M. R., \& Kamriani, N. (2021). The Impact of Job Creation Act Against the Participatory Principle in Environmental Law, International Journal of Law, Environment, and Natural Resources, 1(1), 22-28. https://doi.org/10.51749/injurlens.v1i1.3

${ }^{12}$ Philipus M. Hadjo, 2010, Perlindungan Hukum Bagi Rakyat, Surabaya: Bina Ilmu, hlm. 38.
} 
memiliki otoritas tertinggi untuk menentukan kepentingan manusia yang perlu diatur dan dilindungi. ${ }^{13}$

Menurut R. La Porta bentuk perlindungan hukum yang diberikan oleh suatu negara memiliki dua sifat, yaitu bersifat pencegahan (prohibited) dan bersifat hukuman (sanction). ${ }^{14}$ Bentuk perlindungan hukum yang paling nyata adalah adanya institusi-institusi penegak hukum seperti pengadilan, kejaksaan, kepolisian, dan lembaga-lembaga penyelesaian sengketa diluar pengadilan (non-litigasi) lainnya. Perlindungan yang dimaksud dengan bersifat pencegahan (prohibited) yaitu membuat peraturan, Sedangkan Perlindungan yang dimaksud bersifat hukuman (sanction) yaitu menegakkan peraturan. Adapun tujuan serta cara pelaksanananya antara lain sebagai berikut ${ }^{15}$ :

1. Membuat peraturan yang bertujuan untuk:

a) Memberikan hak dan kewajiban;

b) Menjamin hak-hak pra subyek hukum.

2. Menegakkan peraturan melalui:

a) Hukum administrasi negara yang berfungsi untuk mencegah terjadinya pelanggaran hak-hak dengan perizinan dan pengawasan;

b) Hukum pidana yang berfungsi untuk menanggulangi setiap pelanggaran terhadap peraturan perundang-undangan, dengan cara mengenakan sanksi hukum berupa sansksi pidana dan hukuman.

c) Hukum perdata yang berfungsi untuk memulihkan hak dengan membayar kompensasi atau ganti kerugian.

Berdasarkan hal tersebut maka perlindungan hukum pada umumnya di bagi menjadi dua macam yaitu sebagai berikut:

1. Sarana Perlindungan Hukum Preventif, Pada perlindungan hukum preventif ini, subyek hukum diberikan kesempatan untuk mengajukan keberatan atau pendapatnya sebelum suatu keputusan pemerintah mendapat bentuk yang definitif. Tujuannya adalah mencegah terjadinya sengketa. Perlindungan hukum preventif sangat besar

${ }^{13}$ Perlindungan hukum harus melihat tahapan yakni perlindungan hukum lahir dari suatu ketentuan hukum dan segala peraturan hukum yang diberikan oleh masyarakat yang pada dasarnya merupakan kesepakatan masyarakat tersebut untuk mengatur hubungan prilaku antara anggota-anggota masyarakat dan antara perseorangan dengan pemerintah yang dianggap mewakili kepentingan masyarakat. Lihat Philippe Nonet \& Philip Selznick, (2003), Hukum Responsif, Pilihan di Masa Transisi, Penerjemah Rafael Edy Bosco, Jakarta: Ford Foundation-HuMa, hlm. 23

14 R. La Porta, (2000), "Investor Protection and Corporate Governance", Journal of Financial Economics, Vol. 58, No. 1 January, hlm. 2

${ }_{15}$ Wahyu Sasongko, (2007), Ketentuan-Ketentuan Pokok Hukum Perlindungan Konsumen, Bandar Lampung:Universitas lampung, hlm. 31 
artinya bagi tindak pemerintahan yang didasarkan pada kebebasan bertindak karena dengan adanya perlindungan hukum yang preventif pemerintah terdorong untuk bersifat hati-hati dalam mengambil keputusan yang didasarkan pada diskresi.

2. Sarana Perlindungan Hukum Represif, Perlindungan hukum yang represif bertujuan untuk menyelesaikan sengketa. Penanganan perlindungan hukum oleh Pengadilan Umum dan Peradilan Administrasi di Indonesia termasuk kategori perlindungan hukum ini. Prinsip perlindungan hukum terhadap tindakan pemerintah bertumpu dan bersumber dari konsep tentang pengakuan dan perlindungan terhadap hak-hak asasi manusia karena menurut sejarah dari barat, lahirnya konsep-konsep tentang pengakuan dan perlindungan terhadap hak-hak asasi manusia diarahkan kepada pembatasanpembatasan dan peletakan kewajiban masyarakat dan pemerintah. Prinsip kedua yang mendasari perlindungan hukum terhadap tindak pemerintahan adalah prinsip negara hukum. Dikaitkan dengan pengakuan dan perlindungan terhadap hak-hak asasi manusia, pengakuan dan perlindungan terhadap hak-hak asasi manusia mendapat tempat utama dan dapat dikaitkan dengan tujuan dari negara hukum.

Merujuk argumentasi bahwa Pancasila sebagai dasar falsafah negara yang melandasi "perlindungan hukum bagi rakyat", konsep perlindungan hukum di Indonesia harus dimaknai adalah penghayatan atas kesadaran akan perlindungan bagi harkat dan martabat manusia yang bersumber pada asas Negara Hukum Pancasila. Kepustakaan secara teoritis menganalisis "sarana perlindungan hukum bagi rakyat, titik sentranya pada "tindakan hukum pemerintah", karena itu disebutkan ada dua sarana yaitu: (1) perlindungan hukum preventif, dan (2) perlindungan hukum represif. Dalam kepustakaan dinyatakan bahwa sarana perlindungan hukum preventif yang bertujuan mencegah terjadinya sengketa perkembangannya agak ketinggalan dibandingkan perlindungan hukum represif yang bertujuan untuk menyelesaikan sengketa. Namun diakui pula kini perlindungan hukum preventif mempunyai peranan penting.

Perlindungan hukum yang ditempuh melalui suatu legislasi memiliki asas hukum yang mendasarinya. Demikian pula perlindungan hukum yang ditempuh melalui upaya pembuatan dan pencantuman langkah-langkah melalui legislasi yang memiliki tujuan, ruang lingkup direncanakan melalui setrategi dan kebijakan. ${ }^{16}$ Semua hal itu dapat dijumpai dalam setiap legislasi yang utama diadakan dengan persamaan tujuan yaitu perlindungan hukum. Pound

\footnotetext{
${ }^{16}$ Harliansyah, H., Rini, A. S. ., Siagian, E. N. ., Andjab, T. K. ., \& Fall, R. (2021). Free, Prior And Informed Consent In Fulfilling The Constitutional Rights Of Citizens In The Mining Sector. International Journal of Law, Environment, and Natural Resources, 1(1), 11-21. https://doi.org/10.51749/injurlens.v1i1.2
} 
mengklasifikasikan kepentingan-kepentingan yang dilindungi oleh hukum dalam 3 (tiga) kategori pokok, meliputi kepentingan-kepentingan umum (public interests), Kepentingankepentingan kemasyarakatan (social interests), kepentingan-kepentingan pribadi (private interests). Dworkin menyatakan bahwa hak merupakan yang harus dijunjung tinggi oleh siapapun. Sebagaiman tulisan Dworkin "Rights are best understood as trumps over some backround justication for political decisions that the sate at goal for the community as a whole" (hak paling tepat dipahami sebagai nilai yang paling tinggi atas justifikasi latar belakang bagi keputusan politik yang menyatakan suatu tujuan bagi masyarakat secara keseluruhan). Namun, ketika menghadapi pertentangan antara pelaksanaan hak dengan kepentingan umum maka dibenarkan peniadaan hak. Sehingga konsep pemikiran Dworkin ini tidak sejalan dengan konsep keadilan yang ditawarkan oleh John Rawls. ${ }^{17}$ Bahwa Dworkin mengakui bahwa campur tangan dalam kehidupan individu untuk meniadakan hak dibenarkan, jika dapat ditemukan dasar yang khusus. Menurut Dworkin, sebagaimana yang dikutip oleh Peter Mahmud Marzuki menyatakan, "hak bukan apa yang dirumuskan melainkan nilai yang mendasari perumusan itu". Hakekat hak begitu berharga sehingga memunculkan teori kepentingan dan teori kehendak, sebagaimana yang dikemukakan oleh Jeremy Bentham yang memandang bahwa, "hak adalah kepentingan-kepentingan yang dilindungi oleh hukum". ${ }^{18}$ Kepentingan sosial adalah ketertiban hukum, keamanan nasional, perlindungan ekonomi masyarakat, perlindungan agama, moral, hak-hak kemanusiaan, hasilhasil penemuan, kesehatan dan kesatuan ras, lingkungan, kepentingan-kepentingan perorangan, kepentingan-kepentingan keluarga. Dengan adanya jaminan kebebasan serta kesetaraan yang sama bagi semua orang maka keadilan akan terwujud. ${ }^{19}$ Hak merupkan kekuasaan yang diberikan hukum kepada seseorang hubungan yang erat antara hak dan kewajiban, hak berpasangan dengan kewajiban, artinya jika seseorang mempunyai hak, maka pasangannya adalah adanya kewajiban pada orang lain. ${ }^{20}$ Hak merupakan sesuatu yang melekat pada manusia secara kodrati dan karena adanya hak inilah diperlukan hukum untuk menjaga kelangsungan eksistansi hak dalam pola kehidupan bermasyarakat, dan karena adanya hak inilah maka hukum diciptakan. Kepentingan-kepentingan ini bukan diciptakan

\footnotetext{
${ }^{17}$ M. Yasir Said \& Yati Nurhayati, (2021), “A Review on Rawls Theory of Justice”, International Journal of Law, Environment, and Natural Resources, Vol.1, Issue.1, April 2021, PP.29-36

${ }_{18}$ Peter Mahmud Marzuki, (2006), Pengantar Ilmu Hukum, Jakarta: Kencana Prenada Media Group, hlm. 176.

19 Agus Yudho Hermoko, (2008), Asas Proporsionalitas Dalam Kontrak Komersil, Yogyakarta: Laksbang Mediatma, hlm. 45.

${ }^{20}$ Ibid., hlm. 55.
} 
oleh negara karena kepentingan-kepentingan itu telah ada dalam kehidupan bermasyarakat dan negara hanya memilihnya mana yang harus dilindungi. Menurut Peter Mahmud terdapat 3 (tiga) unsur pada suatu hak, yaitu 1. Unsur perlindungan; 2. Unsur pengakuan; dan 3. Unsur kehendak. Apabila prinsip keadilan dijalankan maka lahir bisnis yang baik dan etis. ${ }^{21}$

Perlindungan merupakan unsur yang penting dalam hak, sebagaimana pendapat Houwing melihat "hak sebagai suatu kepentingan yang dilindungi oleh hukum dengan cara tertentu." 22 Hukum harus mempertimbangkan kepentingan-kepentingan secara cermat dan menciptakan keseimbangan antara kepentingan-kepentingan itu. Van Dijk dalam Peter Mahmud Marzuki menyatakan bahwa "hukum harus berfungsi dalam mencapai tujuan damai sejahtra, tujuan untuk mencapai damai sejahtra itu dapat terwujud apabila hukum sebanyak mungkin memberikan pengaturan yang adil." 23

Perlindungan hukum yang diberikan bagi rakyat Indonesia merupakan implementasi atas prinsip pengakuan dan perlindungan terhadap harkat dan martabat manusia yang bersumber pada pancasila dan prinsip Negara hukum yang berdasarkan Pancasila. ${ }^{24}$ Setiap orang berhak mendapatkan perlindungan dari hukum. Hampir seluruh hubungan hukum harus mendapat perlindungan dari hukum. Oleh karena itu terdapat banyak macam perlindungan hukum. Menurut Teguh Prasetyo, "Teori keadilan bermartabat tidak hanya melihat sistem hukum positif Indonesia secara tertutup dalam pengertian dimana ada masyarakat disitu selalu saja ada hukum". ${ }^{25}$ Lebih lanjut ia menjelaskan "Sistem hukum pancasila adalah sistem hukum kepunyaan bangsa Indonesia sendiri bagian dari warisan peradaban dunia (the produck of civilization). Sistem hukum pancasila adalah sistem hukum hukum yang otentik, orisinal atau belakangan orang suka menyebutnya ori." ${ }^{26}$ Dengan demikian dalam usaha merumuskan prinsip perlindungan hukum bagi rakyat berdasarkan pancasila, diawali dengan uraian tentang konsep dan deklarasi tentang hak-hak asasi manusia. Pancasila dijadikan sebagai dasar ideologi dan dasar falsafah Negara bangsa Indonesia. Oleh karena itu pengakuan terhadap harkat dan martabat manusia bangsa Indonesia bukanlah hasil suatu

${ }^{21}$ Satjipto Rahardjo, (2010), Teori Hukum Strategi Tertib Manusia Linmas Ruang dan General, Yogyakarta: Genta Publishing, hlm. 44

${ }^{22}$ Ibid., hlm. 221

${ }^{23}$ Peter Mahmud Marzuki, (2006), Op.Cit., hlm. 221

${ }^{24}$ Taufiqurrohman, A. (2021). Religions In The Constitution Of Asean Countries: The Rule of Law and Welfare Concept. International Journal of Law, Environment, and Natural Resources, 1(1), 37-46. https://doi.org/10.51749/injurlens.v1i1.5

${ }^{25}$ Teguh Prasetyo, (2015), Keadilan Bermartabat Perspektif Teori Hukum, Bandung: Nusa Media, hlm.58.

${ }^{26}$ Teguh Prasetyo, (2016), Sistem hukum Pancasila, Bandung: Nusa Media, hlm. 3-4. 
perjuangan bertahun-tahun tetapi pengakuan itu secara intrinsic melekat pada pancasila yang tercermin dalam sila-silanya.

M. Isnaeni berpendapat pada dasarnya persoalan perlindungan hukum itu ditinjau dari sumbernya dapat dibedakan menjadi dua (2) macam yakni perlindungan hukum "eksternal" dan perlindungan hukum "internal." ${ }^{27}$ Hakekat perlindungan hukum internal, pada dasarnya perlindungan hukum yang dimaksud dikemas sendiri oleh para pihak pada saat membuat perjanjian, di mana pada waktu mengemas klausula-klausula kontrak, kedua belah pihak menginginkan agar kepentingannya terakomodir atas dasar kata sepakat. Demikian juga segala jenis resiko diusahakan dapat ditangkal lewat pemberkasan lewat klausula-klausula yang dikemas atas dasar sepakat pula, sehingga dengan klausula itu para pihak akan memperoleh perlindungan hukum berimbang atas persetujuan mereka bersama. Perihal perlindungan hukum internal seperti itu baru dapat diwujudkan oleh para pihak, manakala kedudukan hukum mereka relatif sederajad dalam arti para pihak mempunyai bargaining power yang relatif berimbang, sehingga atas dasar asas kebebasan berkontrak masing-masing rekan seperjanjian itu mempunyai keleluasaan untuk menyatakan kehendak sesuai kepentingannya. Pola ini dijadikan landasan pada waktu para pihak merakit klausula-klausula perjanjian yang sedang digarapnya, sehingga perlindungan hukum dari masing-masing pihak dapat terwujud secara lugas atas inisiatif mereka. ${ }^{28}$ Perlindungan hukum eksternal yang dibuat oleh penguasa lewat regulasi bagi kepentingan pihak yang lemah, sesuai hakekat aturan perundangan yang tidak boleh berat sebelah dan bersifat memihak, secara proporsional juga wajib diberikan perlindungan hukum yang seimbang sedini mungkin kepada pihak lainnya. ${ }^{29}$

Berdasarkan penjelasan diatas, tergambar bagaimana kewajiban penguasa itu dalam memberikan perlindungan hukum kepada para pihak secara proporsional. Sama hal nya dengan perlindungan tenaga kesehatan maka harus dilaksanakan secara seimbang dan berkeadilan. Tentu menerbitkan aturan hukum dengan model seperti itu, bukan tugas yang mudah bagi pemerintah, tetapi tidak bisa dipungkiri adalah suatu kewajiban negara yang harus secara optimal untuk melindungi rakyatnya.

\section{B. Upaya Perlindungan Hukum dan Pemenuhan Hak untuk Memperoleh Keselamatan Kerja Bagi Tenaga Kesehatan Selama Pandemi Covid-19}

\footnotetext{
${ }^{27}$ Moch. Isnaeni, (2016), Pengantar Hukum Jaminan Kebendaan, Surabaya: PT. Revka Petra Media,
} hlm. 159.

${ }^{28}$ Ibid., hlm. 160. hlm. 163 .

${ }^{29}$ Moch. Isnaeni, (2016), Pengantar Hukum Jaminan Kebendaan, Surabaya: PT. Revka Petra Media, 
Perlindungan hukum bagi keselamatan kerja tenaga kesehatan merupakan aspek yang penting ditengah pandemi covid-19. Pada prakteknya, tenaga kesehatan sering kali tidak mendapatkan hak-hak yang seharusnya terpenuhi, seperti halnya ketersediaan alat pelindung diri (APD). Padahal, pemerintah juga harus memperhatikan keselamatan tenaga kesehatan dalam menangani wabah Covid-19 dengan memenuhi ketersediaan APD. Secara hukum tenaga kesehatan sudah dilengkapi dengan kewajiban dan hak-hak hukum dan perlindungan yang diatur didalam perundang-undangan. Adapun ketentuan norma-norma tersebut antara lain diatur pada:

Tabel 1.

Produk Hukum Tentang Perlindungan Hukum Tenaga Kesehatan

\begin{tabular}{|c|c|c|}
\hline \multirow{2}{*}{ No } & Produk Hukum & Norma \\
\hline & \multicolumn{2}{|c|}{ Keadaan Normal } \\
\hline 1 & $\begin{array}{l}\text { UU No. } 29 \text { Tahun } 2004 \text { tentang Praktik } \\
\text { Kedokteran }\end{array}$ & $\begin{array}{l}\text { Pasal 50: Dokter atau dokter gigi } \\
\text { mempunyai hak memperoleh perlindungan } \\
\text { hukum sepanjang melaksanakan tugas } \\
\text { sesuai dengan standar profesi dan standar } \\
\text { prosedur operasional. }\end{array}$ \\
\hline 2 & $\begin{array}{l}\text { UU No. } 36 \text { Tahun } 2009 \text { tentang } \\
\text { Kesehatan }\end{array}$ & $\begin{array}{l}\text { Pasal 82-83: Setiap orang yang memberikan } \\
\text { pelayanan kesehatan pada bencana harus } \\
\text { ditujukan untuk penyelamatan nyawa, } \\
\text { pencegahan kecacatan lebih lanjut, dan } \\
\text { kepentingan bagi pasien. Pemerintah } \\
\text { menjamin perlindungan hukum setiap orang } \\
\text { sebagaimana dimaksud pada ayat (1) sesuai } \\
\text { dengan kemampuan yang dimiliki. }\end{array}$ \\
\hline 3 & $\begin{array}{l}\text { UU No.44 Tahun } 2009 \text { tentang Rumah } \\
\text { Sakit }\end{array}$ & $\begin{array}{l}\text { Pasal 3: Penyelenggaraan rumah sakit } \\
\text { bertujuan memberikan perlindungan } \\
\text { terhadap keselamatan pasien, masyarakat, } \\
\text { lingkungan rumah sakit \& sdm di RS. } \\
\text { Pasal 30: RS mempunyai hak mendapatkan } \\
\text { perlindungan hukum dalam melaksanakan } \\
\text { pelayanan kesehatan }\end{array}$ \\
\hline 4 & $\begin{array}{l}\text { Permenkes No.1438/2010 tentang } \\
\text { Standar } \\
\text { Pelayanan Kedokteran }\end{array}$ & $\begin{array}{l}\text { Pasal 13: Modifikasi terhadap PNPK } \\
\text { (Pedoman Nasional Pelayanan Kedokteran) } \\
\text { dan SPO (Standar Prosedur Operasional) } \\
\text { hanya dapat dilakukan atas dasar keadaan } \\
\text { yang memaksa untuk kepetingan pasien, } \\
\text { antara lain keadaan khusus pasien, } \\
\text { kedaruratan dan keterbatasan sumber daya. }\end{array}$ \\
\hline 5 & $\begin{array}{l}\text { Permenkes No.66/2016 tentang } \\
\text { Keselamatan \& Kesehatan Kerja di RS }\end{array}$ & $\begin{array}{l}\text { Pasal 3: Setiap RS wajib menyelenggarakan } \\
\text { K3RS (Keselamatan \& Kesehatan Kerja } \\
\text { Rumah Sakit). Lampiran: Kegiatan } \\
\text { promotif, preventif, kuratif, rehabilitatif, }\end{array}$ \\
\hline
\end{tabular}




\begin{tabular}{|c|c|c|}
\hline & & unit layanan kesehatan kerja di RS \\
\hline 6 & $\begin{array}{l}\text { Permenkes No.27/2017 tentang Pedoman } \\
\text { Pencegahan \& Pengendalian Infeksi di } \\
\text { Fasilitas Kesehatan }\end{array}$ & $\begin{array}{l}\text { Pedoman komprehensif yang berisi upaya } \\
\text { pencegahan dan pengendalian infeksi setiap } \\
\text { orang di saat menerima pelayanan kesehatan } \\
\text { pada berbagai fasilitas kesehatan }\end{array}$ \\
\hline & \multicolumn{2}{|c|}{ Keadaan Wabah/Pandemi Kesehatan } \\
\hline 7 & $\begin{array}{l}\text { UU No. 4/1984 tentang Wabah Penyakit } \\
\text { Menular }\end{array}$ & $\begin{array}{l}\text { Pasal 5-9: Kepada mereka yang mengalami } \\
\text { kerugian harta benda yang diakibatkan oleh } \\
\text { upaya penanggulangan wabah dapat } \\
\text { diberikan ganti rugi \& diatur dengan PP. } \\
\text { Pasal 10: Pemerintah bertanggung jawab } \\
\text { untuk melaksanakan upaya penanggulangan } \\
\text { wabah. }\end{array}$ \\
\hline 8 & $\begin{array}{l}\text { UU No. 24/2007 tentang Penanggulangan } \\
\text { Bencana }\end{array}$ & $\begin{array}{l}\text { Pasal 3: Penanggulangan bencana } \\
\text { berasaskan; kemanusiaan, keadilan, } \\
\text { kesamaan kedudukan dalam hukum dan } \\
\text { pemerintahan, keseimbangan, keselarasan, } \\
\text { dan keserasian, ketertiban dan kepastian } \\
\text { hukum; kebersamaan; kelestarian, dan ilmu } \\
\text { pengetahuan dan teknologi. }\end{array}$ \\
\hline 9 & $\begin{array}{l}\text { UU No. } 6 / 2018 \text { tentang Kekarantinaan } \\
\text { Kesehatan }\end{array}$ & $\begin{array}{l}\text { Pasal } 4 \text { : Pemerintah Pusat dan Pemerintah } \\
\text { Daerah bertanggung jawab melindungi } \\
\text { kesehatan masyarakat dari penyakit } \\
\text { dan/atau Faktor Risiko Kesehatan } \\
\text { Masyarakat yang berpotensi menimbulkan } \\
\text { Kedaruratan Kesehatan Masyarakat melalui } \\
\text { penyelenggaraan Kekarantinaan Kesehatan. }\end{array}$ \\
\hline 10 & $\begin{array}{l}\text { Perpres No. 17/2018 tentang } \\
\text { Penyelenggaraan Penanggulangan } \\
\text { Bencana dalam Keadaan Tertentu }\end{array}$ & $\begin{array}{l}\text { Pasal 1 : Risiko bencana adalah potensi } \\
\text { kerugian yang ditimbulkan akibat bencana } \\
\text { pada suatu wilayah dan kurun waktu } \\
\text { tertentu yang dapat merupakan kematian, } \\
\text { luka,sakit, jiwa terancam, hilangnya rasa } \\
\text { aman, mengungsi, kerusakan atau } \\
\text { kehilangan harta, dan gangguan kegiatan } \\
\text { masyarakat. }\end{array}$ \\
\hline 11 & $\begin{array}{l}\text { Permenkes No. } 1501 / 2010 \text { tentang } \\
\text { Penyakit } \\
\text { Menular Tertentu yang dapat } \\
\text { menimbulkan } \\
\text { Wabah \& Upaya Penanggulangan }\end{array}$ & $\begin{array}{l}\text { Pasal } 15 \text { : Penetapan suatu daerah dalam } \\
\text { keadaan KLB/Wabah diperlukan untuk } \\
\text { mempermudah koordinasi \& optimalisasi } \\
\text { sumber daya di bidang kesehatan meliputi } \\
\text { segala bentuk dana, tenaga, perbekalan } \\
\text { kesehatan, sediaan farmasi, dan alat } \\
\text { kesehatan dan teknologi. } \\
\text { Pasal } 24 \text { : Dalam keadaan KLB/Wabah } \\
\text { seluruh faskes baik pemerintah maupun } \\
\text { swasta wajib memberikan pelayanan } \\
\text { terhadap penderita atau tersangka penderita. }\end{array}$ \\
\hline
\end{tabular}




\begin{tabular}{|l|l|l|}
\hline & $\begin{array}{l}\text { Pasal 25 : Dalam keadaan KLB/Wabah, } \\
\text { pemerintah \& pemerintah daerah wajib } \\
\text { menyediakan perbekalan kesehatan meliputi } \\
\text { bahan, alat, obat dan vaksin serta bahan/alat } \\
\text { pendukung lainnya. }\end{array}$ \\
\hline Permenkes No. 82/2014 tentang & $\begin{array}{l}\text { Pasal 27 : Sumber daya manusia dalam } \\
\text { penyelenggaraan Penanggulangan Penyakit } \\
\text { Penanggulangan Penyakit Menular }\end{array}$ \\
& $\begin{array}{l}\text { Menaga meliputi tenaga kesehatan dan } \\
\text { kompetensi yang sesuai dengan kegiatan } \\
\text { penanggulangan. }\end{array}$ \\
\hline Sumber: Tri Aktariyani dkk., 2020
\end{tabular}

Berdasarkan Permenkes No. 66/2016 tentang Keselamatan \& Kesehatan Kerja di Rumah Sakit, maka tenaga kesehatan juga harus mengikuti protokol keselamatan dan kesehatan kerja selama menangani pandemi covid-19. Adapun pedoman protokol tersebut diatur didalam Permenkes No. 27/2017 tentang Pedoman Pencegahan \& Pengendalian Infeksi di Fasilitas Kesehatan. Kendati demikian ketentuan-ketentuan tersebut belum mengatur secara khusus mengenai potensi bahaya penyebaran virus covid-19.

Mengenai hak-hak tenaga kesehatan yang dilindungi oleh hukum. Maka merujuk pada Pasal 57 Undang-Undang Tenaga Kesehatan menyebutkan bahwa Tenaga kesehatan dalam menjalankan praktik berhak:

1) Memperoleh perlindungan hukum sepanjang melaksanakan tugas sesuai dengan Standar Profesi, Standar Pelayanan Profesi, dan Standar Prosedur Operasional;

2) Memperoleh informasi yang lengkap dan benar dari penerima pelayanan kesehatan atau keluarganya;

3) Menerima imbalan jasa;

4) Memperoleh perlindungan atas keselamatan dan kesehatan kerja, perlakuan yang sesuai dengan harkat dan martabat manusia, moral, kesusilaan, serta nilai-nilai agama;

5) Mendapatkan kesempatan untuk mengembangkan profesinya;

6) Menolak keinginan penerima pelayanan kesehatan atau pihak lain yang bertentangan dengan standar profesi, kode etik, standar pelayanan, standar prosedur operasional, atau ketentuan peraturan perundang-undangan; dan

7) Memperoleh hak lain sesuai dengan ketentuan peraturan perundang-undangan.

Dari bunyi Pasal 57 Undang-Undang Tenaga Kesehatan di atas, maka profesi tenaga kesehatan sangat perlu mendapatkan perlindungan hukum dalam melaksanakan tugasnya, serta berhak atas keselamatan dan kesehatan kerja dalam memberikan pelayanan kesehatan. 
Namun saat pandemic Covid-19 ini, banyak tenaga kesehatan yang harus mengorbankan nyawanya untuk menanggulangi penyebaran Covid-19 sampai terpapar dan meninggal.

Tak hanya itu, pemerintah juga bertanggung jawab dalam menyediakan fasilitas pelayanan kesehatan bagi para tenaga kesehatan untuk menjalankan pekerjaannya. Oleh karenanya, Pemerintah Pusat dan Pemerintah Daerah bertanggung jawab atas ketersediaan fasilitas pelayanan kesehatan dalam rangka mewujudkan derajat kesehatan yang setinggitingginya. Hal ini diatur dan tertuang dalam Pasal 6 Peraturan Pemerintah Nomor 47 Tahun 2016 tentang Fasilitas Pelayanan Kesehatan.

Mengingat wabah penyebaran Covid-19 saat ini berstatus bencana setelah dikeluarkannya SK Kepala BNPB Nomor 13 A Tahun 2020, maka seluruh jajaran Pemerintah wajib menjalankan seluruh kewajibannya sebagaimana diatur dalam perundang-undangan yang berlaku. Kewajiban yang seharusnya dipenuhi oleh Pemerintah ini, termasuk:

1) Mendukung ketersediaan peralatan kesehatan di lapangan;

2) Menjamin terpenuhinya hak-hak masyarakat dan para tenaga medis;

3) Transparansi informasi informasi kepada publik;

4) Pengambilan kebijakan yang memperhatikan nilai-nilai hak asasi manusia dan demokrasi.

\section{PENUTUP}

\section{A. Kesimpulan}

Berdasarkan pembahasan mengenai permasalahan atas perlindungan hukum dan pemenuhan hak untuk memperoleh keselamatan kerja bagi tenaga medis yang menangani pandemi covid-19 maka dapat disimpulkan bahwa diatur pada Permenkes No.66/2016 tentang Keselamatan \& Kesehatan Kerja di Rumah Sakit, bahwa tenaga kesehatan juga harus mengikuti protokol keselamatan dan kesehatan kerja selama menangani pandemi covid-19. Adapun pedoman protokol tersebut diatur didalam Permenkes No.27/2017 tentang Pedoman Pencegahan \& Pengendalian Infeksi di Fasilitas Kesehatan. Kendati demikian ketentuanketentuan tersebut belum mengatur secara khusus mengenai potensi bahaya penyebaran virus covid-19.

\section{B. Saran}

Pemerintah harus mengupayakan perlindungan hukum dan pemenuhan hak yang ideal untuk memperoleh keselamatan kerja bagi tenaga medis yang menangani pandemi covid-19 sebagai 
garda terdepan penanganan pandemi. Adapun dalam hal ini perlindungan dirumuskan dengan suatu kebijakan yang responsif agar tenaga medis dapat terpenuhi haknya secara proporsional

\section{Buku}

\section{DAFTAR PUSTAKA}

Agus yudho Hermoko, (2008), Asas Proporsionalitas Dalam Kontrak Komersil, Yogyakarta: Laksbang Mediatma.

Moch. Isnaeni, (2016), Pengantar Hukum Jaminan Kebendaan, Surabaya: PT. Revka Petra Media.

Moch. Isnaeni, (2016), Pengantar Hukum Jaminan Kebendaan, Surabaya: PT. Revka Petra Media.

Philipus M. Hadjo, 2010 , Perlindungan Hukum Bagi Rakyat, Surabaya: Bina Ilmu.

Peter Mahmud Marzuki, (2006), Pengantar Ilmu Hukum, Jakarta: Kencana Prenada Media Group.

Philippe Nonet \& Philip Selznick, (2003), Hukum Responsif, Pilihan di Masa Transisi, Penerjemah Rafael Edy Bosco, Jakarta: Ford Foundation-HuMa.

Peter Mahmud Marzuki. (2005). Penelitian Hukum, Jakarta: Kencana.

Soerjono Soekanto dan Sri Mamuji. (1995). Penelitian Hukum Normatif, Suatu Tinjauan Singkat, Jakarta: Raja Grafindo.

Satjipto Rahardjo, (2010), Teori Hukum Strategi Tertib Manusia Linmas Ruang dan General, Yogyakarta: Genta Publishing.

Teguh Prasetyo, (2015), Keadilan Bermartabat Perspektif Teori Hukum, Bandung: Nusa Media.

Teguh Prasetyo, (2016), Sistem hukum Pancasila, Bandung: Nusa Media.

Wahyu Sasongko, (2007), Ketentuan-Ketentuan Pokok Hukum Perlindungan Konsumen, Bandar Lampung:Universitas lampung.

Yati Nurhayati, Pengantar Ilmu Hukum, Nusa Media, Bandung, 2020.

\section{Peraturan Perundang-Undangan}

Undang-Undang Nomor 29 Tahun 2004 Tentang Praktik Kedokteran

Undang-Undang Nomor 24 Tahun 2007 Tentang Penanggulangan Bencana 
Undang-Undang Nomor 36 Tahun 2009 Tentang Kesehatan

Undang-Undang Nomor 44 Tahun 2009 Tentang Rumah Sakit

Undang-Undang Nomor 4 Tahun 1984 Tentang Wabah Penyakit Menular

Undang-Undang Nomor 6 Tahun 2018 Tentang Kekarantinaan Kesehatan

Permenkes Nomor 1501 Tahun 2010 Tentang Penyakit Menular

Permenkes Nomor 66 Tahun 2016 Tentang Keselamatan \& Kesehatan Kerja di Rumah Sakit

Permenkes Nomor 27 Tahun 2017 Tentang Pedoman Pencegahan \& Pengendalian Infeksi di Fasilitas Kesehatan.

Permenkes Nomor 1438 Tahun 2010 Tentang Standar Pelayanan Kedokteran

\section{Jurnal}

Harliansyah, H., Rini, A. S. ., Siagian, E. N. ., Andjab, T. K. ., \& Fall, R. (2021). Free, Prior And Informed Consent In Fulfilling The Constitutional Rights Of Citizens In The Mining Sector. International Journal of Law, Environment, and Natural Resources, 1(1), 11-21. https://doi.org/10.51749/injurlens.v1i1.2

Ifrani, I., Topan, M. ., Safitri, N. ., \& Erniyati, T. (2021). "Regional Policy In Managing Oil Palm Waste As Renewable Energy In South Kalimantan Province”, International Journal of Law, Environment, and Natural Resources, 1(1), 1-10. https://doi.org/10.51749/injurlens.v1i1.6

M. Yasir Said \& Yati Nurhayati, (2020), "Paradigma Filsafat Etika Lingkungan Dalam Menentukan Arah Politik Hukum Lingkungan”, Al-Adl Jurnal Hukum, Vol.12, No.1 Januari 2020.

M. Yasir Said \& Yati Nurhayati, (2021), "A Review on Rawls Theory of Justice", International Journal of Law, Environment, and Natural Resources, Vol.1, Issue.1, April 2021, PP.29-36

Nurhayati, Y., Ifrani, I., \& Said, M. Y. (2021). Metodologi Normatif Dan Empiris Dalam Perspektif Ilmu Hukum. Jurnal Penegakan Hukum Indonesia, 2(1), 1-20. https://doi.org/10.51749/jphi.v2i1

Noor Rahmah, A., Ridha, M. R., \& Kamriani, N. (2021). The Impact of Job Creation Act Against the Participatory Principle in Environmental Law, International Journal of Law, Environment, and Natural Resources, 1(1), 22-28. https://doi.org/10.51749/injurlens.v1i1.3

R. La Porta, (2000), "Investor Protection and Corporate Governance", Journal of Financial Economics, Vol. 58, No. 1 January. 
Taufiqurrohman, A. (2021). Religions In The Constitution Of Asean Countries: The Rule of Law and Welfare Concept. International Journal of Law, Environment, and Natural Resources, 1(1), 37-46. https://doi.org/10.51749/injurlens.v1i1.5

Theresia Louize Pesulima dan Yosia Hetharie, (2020), "Perlindungan Hukum Terhadap Keselamatan Kerja Bagi Tenaga Kesehatan Akibat Pandemi Covid-19", Jurnal Sasi, Vol. 26, No. 2, April-Juni 2020.

Tri Aktariyani, Darwito, Rimawati, \& Laksono Trisnantoro, (2020), "Perlindungan Hukum Residen Dalam Penanganan Pasien Covid-19 Di Indonesia", Jurnal Kebijakan Kesehatan Indonesia : JKKI, Vol.9, No.4, Desember 2020.

Yati Nurhayati, "Perdebatan Metode Normatif dengan Metode Empirik Dalam Penelitian Ilmu Hukum Ditinjau Dari Karakter, Fungsi dan Tujuan Ilmu Hukum”, Jurnal Al Adl, Volume 5 Nomor 10, 2013.

\section{Internet}

Heldavidson, "First Covid-19 Case Happened In November, China Government Records Show - 2020", Report diakses dari https://www.theguardian.com/world/2020/mar/13/first-covid-19-case-happenedin-november-china-government-records-show-report. (Diakses tanggal 20 Februari 2021)

Merdeka.com/Data PPNI: Perawat Meninggal Akibat Covid-19, (Diakses tangal 6 Maret 2020). 